\title{
ANALISIS KONEKTIVITAS DAN KARAKTERISTIK LORONG PADA SISTEM HIDROGEOLOGI MATAAIR BETON, KAWASAN KARST GUNUNGSEWU, KABUPATEN GUNUNGKIDUL DENGAN UJI PERUNUTAN
}

\author{
Ahmad Cahyadi1,2, Eko Haryono1,2, Tjahyo Nugroho Adji ${ }^{1,2}$, M Widyastuti1,2, \\ Muhammad Naufal1,2, Fajri Ramadhan,,2, Romza Fauzan Agniy,2,3, Indra Agus Riyanto 2,3 \\ ${ }^{1}$ Departemen Geografi Lingkungan, Fakultas Geografi, Universitas Gadjah Mada \\ ${ }^{2}$ Kelompok Studi Karst, Fakultas Geografi, Universitas Gadjah Mada \\ ${ }^{3}$ Magister Perencanaan Pengelolaan Pesisir dan Daerah Aliran Sungai (MPPDAS), \\ Fakultas Geografi, Universitas Gadjah Mada, Bulaksumur, \\ Depok, Sleman, 55821, Yogyakarta, Indonesia \\ Email: ahmadcahyadi@geo.ugm.ac.id
}

Diterima: 02 November 2019, Direvisi: 03 Mei 2020, Disetujui: 02 Juni 2020

\begin{abstract}
Abstrak
Pemahaman tentang sistem hidrogeologi dan wilayah tangkapan air dari sebuah mata air sangatlah penting. Hal ini untuk membantu pengelolaan yang menjaga kelestariannya. Mataair Beton merupakan salah satu mataair yang memiliki peranan yang sangat penting di wilayah Ponjong, Kabupaten Gunungkidul. Suplai air dari mataair ini digunakan untuk memenuhi kebutuhan air bersih, irigasi persawahan dan perikanan. Penelitian ini bertujuan untuk mengetahui konektivitas dan karakterisasi lorong di sistem hidrogeologi Mataair Beton. Metode yang digunakan adalah tracer test dengan menggunakan fluorescent dyes. Hasil analisis menunjukkan bahwa Ponor Seropan memiliki konektivitas dengan Mataair Beton, dan memiliki karakteristik lorong berupa single conduit. Perkembangan lorong yang lanjut menunjukkan bahwa sistem hidrogeologi di lokasi kajian sangat dipengaruhi oleh imbuhan airtanah dari sistem alogenik yang berhulu di wilayah non-karst dan memiliki kerentanan terhadap pencemaran airtanah yang tinggi.
\end{abstract}

Kata Kunci: Karst, Sungai Alogenik, Kawasan Karst Gunung Sewu, Uji Perunutan, Mataair Beton

\begin{abstract}
An understanding of the hydrogeological system and catchment area of spring is very important. This is to help manage that maintains its sustainability. Beton Resurgence is one of the springs that have a very important role in the Ponjong area, Gunungkidul Regency. Water supply from the spring is used to supply clean water, irrigated rice fields, and fisheries. This study aims to determine the connectivity and characterization of Passage in the Beton hydrogeological system. The method used is a tracer test using fluorescent dyes. The results of the analysis of breaktrough curve indicate that Seropan Sinking Stream has connectivity with Beton resurgence, and has passage characteristics in the form of a single conduit. The further development of the passage shows that the hydrogeological system is strongly influenced by groundwater recharge originating from an allogenic system that originates in non-karst areas and has a high groundwater vulnerability to pollution.
\end{abstract}

Keywords: Karst, Allogenic River, Gunungsewu Karst Area, Tracer Test, Beton Resurgence 


\section{PENDAHULUAN}

Kawasan karst gunungsewu dikenal dengan kawasan yang sering mengalami kekeringan. Sumberdaya air yang terbatas akibat kondisi geologi yang dikontrol oleh pembentukan lorong pelarutan telah menyebabkan kondisi kering di permukaan. Hal tersebut menyebabkan masyarakat yang tinggal di wilayah tersebut mengalami kesulitan air khususnya pada musim kemarau.

Sumber air utama yang digunakan untuk pemenuhan kebutuhan air bersih di Kawasan Karst Gunungsewu adalah air hujan, telaga, mataair dan sungai bawah tanah. Meskipun demikian, ketersediaan masing-masing sumber air bersih tersebut tidak merata di secara spasial. Oleh karenanya, masing-masing wilayah memiliki karakteristik hidrologi sumber air yang berbeda-beda.

Sub sistem hidrogeologi Ponjong merupakan salah satu sub sistem hidrogeologi di Kawasan Karst Gunungsewu (Cahyadi et al., 2018). Sub sistem hidrogeologi ini memiliki karakteristik berupa kemunculan mataair yang memiliki debit yang besar, arah aliran airtanah ke arah barat dan selatan dan keberadaan sungai bawah tanah yang dipengaruhi oleh imbuhan alogenik (Haryono, 2011; Haryono et al., 2017). Keberadaan imbuhan alogenik tidak terlepas dari kondisi geologi sub sistem hidrogeologi Ponjong yang berbatasan langsung dengan formasi vulkanik tersier yang mengalasinya.

Salah satu mataair yang muncul di sub sistem hidrogeologi Ponjong adalah Mataair Beton (Pratiwi, 2013; Lestari et al., 2014). Mataair ini memiliki peranan yang besar dalam penyediaan air bersih, irigasi persawahan dan perikanan di Kecamatan Ponjong dan karangmojo, Kabupaten Gunungkidul. Luas area yang dialiri oleh jaringan irigasi dari Mataair Beton adalah sekitar 800 hektar. Oleh karenanya, pengelolaan wilayah tangkapan dari mataair ini menjadi sangat penting untuk menjaga keberlangsungan peranannya dalam berbagai kepentingan.

Pemahaman yang baik terkait dengan kondisi hidrogeologi dan wilayah tangkapan air suatu mataair sangat penting untuk mendukung rencana pengelolaan yang akan diterapkan. Namun demikian, perkembangan lorong pelarutan yang acak di kawasan karst dengan ukuran lorong yang beragam mulai dari yang sangat kecil sampai sangat besar seringkali menyulitkan untuk mendefinisikan sistem hidrologi dan wilayah tangkapan air dari suatu mataair. Banyaknya lorong vertikal yang sangat dalam atau keberadaan lorong yang penuh air menyebabkan pemetaan dengan survei gua nyaris tidak dapat dilakukan. Oleh karena itu, kemudian dikembangkan beberapa metode invers modelling yang bersifat grey box (Leibundgut et al., 2009; Gilli, 2015). Ide dari metode ini adalah melihat luaran yang dihasilkan oleh sebuah sistem hidrogeologi, kemudian dianalisis karakteristik sistem yang menghasilkannya. Metode ini biasanya dilakukan dengan menganalisis karakteristik respon mataair terhadap hujan, karakteristik hidrograf, karakteristik hidrogeokimia atau hidrokhemograf, dan dapat pula dengan analisis kurva yang dihasilkan oleh injeksi zat perunut atau disebut dengan breaktrough curve.

Penelitian ini bertujuan untuk mengetahui konektivitas Ponor Seropan dan Mataair Beton yang merupakan bagian kecil dari Sub sistem hidrogeologi Ponjong, Kawasan Karst Gunungsewu (Gambar 1). Secara administratif wilayah kajian meliputi Desa Sawahan dan Desa Umbulrejo, Kecamatan Ponjong, Kabupaten Gunungkidul. Secara geologi, wilayah ini merupakan zona peralihan antara Pegunungan Panggung Masif dengan Kawasan Karst Gunungsewu (Van Bemmelen, 1949). 


\section{ge grafi}

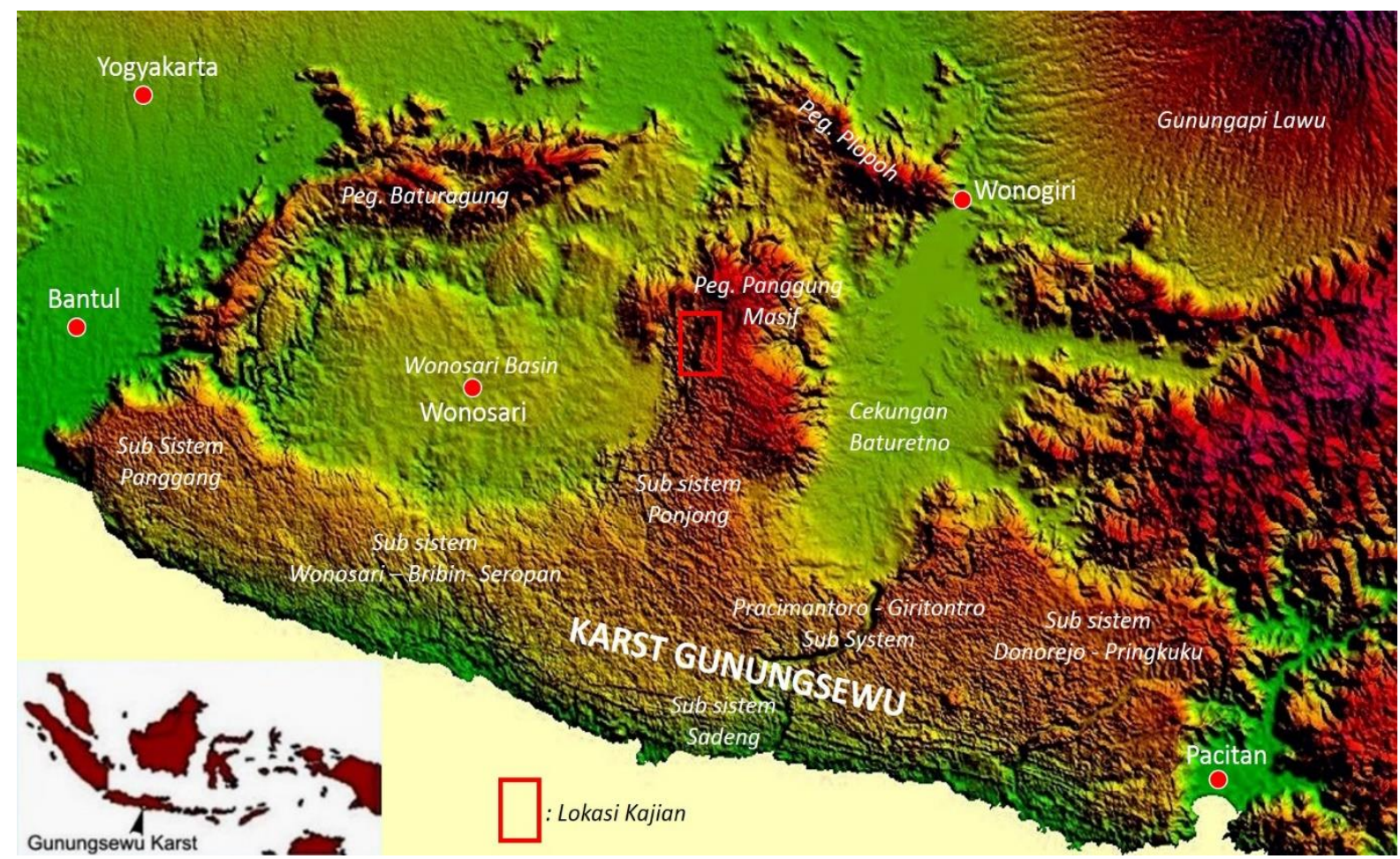

Gambar 1. Lokasi Kajian

\section{METODE PENELITIAN}

Uji perunutan (tracer test) adalah salah satu metode yang digunakan untuk mengetahui konektivitas dua atau lebih saluran konduit pada sistem airtanah isotropis khususnya pada kawasan karst (Stanley et al., 1980). Meskipun metode ini kini telah banyak diaplikasikan untuk analisis aliran airtanah pada media antar butir (sistem anisotropis). Metode perunutuan ini sangat penting terutama ketika penelusuran lorong gua (caving) tidak memungkinkan dilakukan karena lorong yang terlalu sempit, medan yang berat atau terdapat lorong yang penuh dengan air (Hess and White, 1989; Ford and Williams, 2007).

Perkembangan teknologi saat ini memungkinkan metode ini tidak hanya mengandalkan pengamatan visual, tetapi dapat dianalisis dengan lebih detail dengan menggunakan pencatat konsentrasi larutan perunut (Riyanto et al, 2018). Hal ini berimplikasi pada hasil kajian yang tidak hanya berupa konektivitas antar lorong, tetapi dapat pula digunakan untuk menganalisis karakteristik pelorongan yang berkembang melalui analisis breaktroughcurve. Breaktroughcurve adalah fungsi waktu dari konsentrasi larutan perunut yang tercatat pada pencatat (fluorometer).

Bahan perunut yang digunakan dalam penelitian ini adalah uranin. Bahan ini berwarna merah ketika dalam bentuk serbuk, dan berubah menjadi hijau ketika dilarutkan di dalam air. Bahan ini merupakan salah satu jenis fluorescent dyes, sehingga dapat dideteksi dengan menggunakan fluorometer. Kelebihan uranin dibandingkan dengan jenis larutan perunut lain adalah bahwa uranin dapat dideteksi dengan jumlah yang sangan kecil $(0,1 \mu \mathrm{g} / \mathrm{l})$, memiliki warna mencolok, tidak memiliki natural background, dan yang terpenting adalah bersifat aman atau tidak bersifat toksik (Cahyadi dan Agniy, 2016). Kelemahan dari uranin adalah mudah larut 
ge grafi

pada $\mathrm{pH}$ (derajat keasaman) rendah dan sensitif terhadap cahaya. Kedua kelemahan ini secara alamiah tidak terdapat di lokasi penelitian karena sifat air di kawasan karst memiliki $\mathrm{pH}$ yang tinggi (relatif basa) dan
DOI: 10.24114/jg.v12i02.14474

e-ISSN: 2549-7057 | p-ISSN: 2085-8167

digunakan pada sungai bawah tanah yang tidak terpapar langsung oleh cahaya matahari. Secara lengkap karakteristik dari uranin dan zat lain yang sering digunakan untuk uji perunutan disajikan dalam Tabel 1.

Tabel 1. Beberapa Jenis Zat Pelacak yang Sering Digunakan

\begin{tabular}{|c|c|c|c|c|c|c|}
\hline No & Tracer & Jenis & $\begin{array}{c}\text { Batas } \\
\text { Deteksi } \\
(\mu \mathrm{g} / \mathrm{L})\end{array}$ & $\begin{array}{c}\text { Natural } \\
\text { Background }\end{array}$ & Toksikologi & Permasalahan \\
\hline 2 & Uranin & $\begin{array}{l}\text { Fluorescent } \\
\text { dyes } \\
\text { Fluorescent } \\
\text { dyes }\end{array}$ & $10^{-1}$ & & Aman & $\begin{array}{c}\text { Mudah } \\
\text { Terlarut pada } \\
\text { pH rendah } \\
\text { dan Sensitif } \\
\text { Terhadap } \\
\text { Cahaya }\end{array}$ \\
\hline 3 & Sulforhodamine B & $\begin{array}{c}\text { Fluorescent } \\
\text { dyes }\end{array}$ & 10-2 & & $\begin{array}{c}\text { Ecotox,Tidak } \\
\text { Aman }\end{array}$ & \\
\hline 4 & $\begin{array}{l}\text { Amidorhodamine } \\
\text { G }\end{array}$ & $\begin{array}{c}\text { Fluorescent } \\
\text { dyes }\end{array}$ & $10^{-2}$ & Tidak Ada & Aman & \\
\hline 5 & Rhodamine WT & $\begin{array}{c}\text { Fluorescent } \\
\text { dyes }\end{array}$ & & & Genotoxic & \\
\hline 6 & Pyranine & $\begin{array}{c}\text { Fluorescent } \\
\text { dyes }\end{array}$ & & & & $\begin{array}{l}\text { Not Reliable } \\
\text { (Mengalami } \\
\text { Degradasi) }\end{array}$ \\
\hline 7 & Napthionate & $\begin{array}{l}\text { Fluorescent } \\
\text { dyes }\end{array}$ & $10^{-1}$ & & Aman & \\
\hline 8 & Tinopal & $\begin{array}{l}\text { Fluorescent } \\
\text { dyes }\end{array}$ & & & & Mudah Larut \\
\hline $\begin{array}{l}9 \\
10\end{array}$ & $\begin{array}{l}\text { Sodium } \\
\text { Potasium }\end{array}$ & $\begin{array}{l}\text { Garam } \\
\text { Garam }\end{array}$ & $\begin{array}{l}\text { Tergantung } \\
\text { Metode, }\end{array}$ & $\begin{array}{l}\text { Tinggi } \\
\text { Sedang }\end{array}$ & & \\
\hline $\begin{array}{l}12 \\
13 \\
14\end{array}$ & $\begin{array}{l}\text { Strontium } \\
\text { Klorida } \\
\text { Bromida }\end{array}$ & $\begin{array}{l}\text { Garam } \\
\text { Garam } \\
\text { Garam }\end{array}$ & $\begin{array}{c}\text { biasanya } \\
\text { sekitar } 0,1 \\
\mu \mathrm{g} / \mathrm{L} \\
\text { sampai } \\
\text { denoan }\end{array}$ & $\begin{array}{c}\text { Sangat } \\
\text { Rendah } \\
\text { Sedang } \\
\text { Tinggi } \\
\text { Rendah }\end{array}$ & $\begin{array}{c}\text { Aman pada } \\
\text { Batas } \\
\text { Tertentu }\end{array}$ & Mudah Larut \\
\hline 15 & Iodida & Garam & $\begin{array}{l}\text { dengan } \\
\text { 1mg/L }\end{array}$ & $\begin{array}{l}\text { Sangat } \\
\text { Rendah }\end{array}$ & $\begin{array}{l}\text { Belum } \\
\text { Dievaluasi }\end{array}$ & Tidak Stabil \\
\hline 16 & Microspheres & Partikel & $\begin{array}{l}\text { Terdeteksi } \\
\text { sebagai } \\
\text { Partikel }\end{array}$ & Tidak Ada & Aman & $\begin{array}{l}\text { Sulit } \\
\text { Dilakukan } \\
\text { Analisis } \\
\text { Kuantitatif } \\
\text { Analisis }\end{array}$ \\
\hline $\begin{array}{l}18 \\
19\end{array}$ & $\begin{array}{l}\text { Spesific Bacteria } \\
\text { Bacteriophages }\end{array}$ & $\begin{array}{l}\text { Partikel } \\
\text { Partikel }\end{array}$ & Tunggal & & $\begin{array}{c}\text { Belum } \\
\text { Dievaluasi }\end{array}$ & $\begin{array}{c}\text { Membutuhkan } \\
\text { Waktu yang } \\
\text { Lama }\end{array}$ \\
\hline
\end{tabular}

Sumber: Benischke et al. (2007), Behrens et al. (2001), Cahyadi dan Agniy (2016) 
Banyaknya jumlah uranin yang digunakan dalam uji perunutan sangat ditentukan pada jarak antara lokasi injeksi dan lokasi pemasangan fluorometer (L) (Käss, 1998; Field, 2003; Field, 2005; Goldscheider et al., 2008). Jarak antara dua titik tersebut diperkirakan berdasarkan jarak pada peta. Selain itu, beberapa peneliti menambahkan nilai faktor kondisi hidrologi (B) yang umumnya bernilai 0,1 sampai dengan 0,9 dan koefisien zat pelacak (k) yang digunakan. Persamaan yang digunakan dalam penentuan banyaknya zat yang diinjeksikan (M) ditunjukkan pada persamaan 1, sedangkan nilai koefisien zat pelacat (k) dan nilai faktor kondisi hidrologi (B) dapat dilihat pada Tabel 2.

$$
\mathbf{M}=\mathbf{L} . \mathbf{k} . \mathbf{B}
$$

di mana $\mathrm{M}=$ Banyaknya zat yang diinjeksikan dalam satuan kilogram $(\mathrm{Kg}), \mathrm{L}$ $=$ jarak titik injeksi dan lokasi observasi, $\mathrm{k}=$ koefisien zat pelacak dan B = faktor kondisi hidrologi.

Tabel 2. Penentuan Nilai Koefisien Zat Pelacak (k) dan Faktor Kondisi Hidrologi (B)

\begin{tabular}{|c|c|c|c|}
\hline Tracer & Nilai k & Kondisi Hidrologi & Nilai B \\
\hline \multicolumn{4}{|l|}{$\begin{array}{l}\text { Tracer yang Larut dalam Air } \\
\text { (massa dalam kg }\end{array}$} \\
\hline - Uranin & 1 & Aliran permukaan & $0,1-0,9$ \\
\hline - Eosin & 5,5 & Akuifer Karst (Konduit) & \\
\hline - Sulforhodamine B & 4 & Akuifer berupa Pasir/Kerikil & \\
\hline - Amidorhodamine G & 2 & Akuifer dengan Banyak fissure & \\
\hline - Pyranine & 5,5 & $\begin{array}{l}\text { Akuifer berupa pasir dan kerikil } \\
\text { dengan banyak campuran }\end{array}$ & $2-4$ \\
\hline - Naphthionate & 15 & $\begin{array}{l}\text { Injeksi ke airtanah melalui media } \\
\text { tidak jenuh air }\end{array}$ & \\
\hline - Tinopal & 3 & $\begin{array}{l}\text { Gamping dengan aliran pada } \\
\text { rongga antar butir batuan (matrix) }\end{array}$ & \\
\hline - $\mathrm{NaCl}$ & 20.000 & Akuifer dengan sedikit fissure & \\
\hline - $\mathrm{LiCl}$ & 1.000 & Filtrasi tepi sungai & \\
\hline - $\mathrm{KCl}$ & 10.000 & $\begin{array}{l}\text { Air dengan turbiditas tinggi dan } \\
\text { tracer background lebih dari } 0\end{array}$ & \\
\hline Tracer Partikel (jumlah partikel) & & $\begin{array}{l}\text { Injeksi ke airtanah melalui lapisan } \\
\text { tidak jenuh air yang tipis atau } \\
\text { lapisan yang tidak jenuh air yang } \\
\text { berlempung }\end{array}$ & $5-10$ \\
\hline - Mikrosfer & $1 \mathrm{E}+12$ & Kandungan geluh atau lempung & \\
\hline - Bacteriophages & $1 E+13$ & yang tinggi & \\
\hline - Bakteri (Serratia marcescens) & $1 E+13$ & & \\
\hline
\end{tabular}

Sumber: Käss (1998); Goldscheider et al., 2008

\section{HASIL DAN PEMBAHASAN}

Ponor Seropan (Gambar 2) merupakan suatu outlet dari tiga sungai permukaan yang berhulu di Pegunungan
Panggung Masif. Luas area tangkapannya sekitar 12,82 km² (Cahyadi et al., 2018). Wilayah tangkapan merupakan bagian dari Pegunungan Panggung Masif yang memiliki 
batuan yang didominasi oleh batuan vulkanik berumur tersier (Akmaludin et al., 2005; Surono, 2008). Wilayah tersebut meliputi empat gunungapi purba yaitu Gunungapi Purba Manyaran, Gunungapi Purba Panggung, Gunungapi Purba Wuryantoro dan Gunungapi Purba Wonodadi (Bronto et al., 2009).

Keberadaan Ponor Seropan disebabkan adanya kontak batuan antara batuan vulkanik tua dengan batuan gamping yang menempel di atasnya. Perbatasan antara keduanya kemudian membentuk drainase bawah permukaan berupa sungai bawah tanah karena sifat batuan gamping yang mudah larut. Ditinjau dari bentuk mulut Ponor Seropan yang berbentuk menyerupai corong dengan keterjalan yang besar, sungai bawah tanah yang terbentuk disebabkan oleh karena gerakan air yang berada di zona phreatik menuju ke zona jenuh air. Menurut White (1988) tipe lorong yang berupa elliptical passage seperti pada Ponor Seropan merupakan bentukan yang dihasilkan oleh pengaruh hidraulika aliran air.

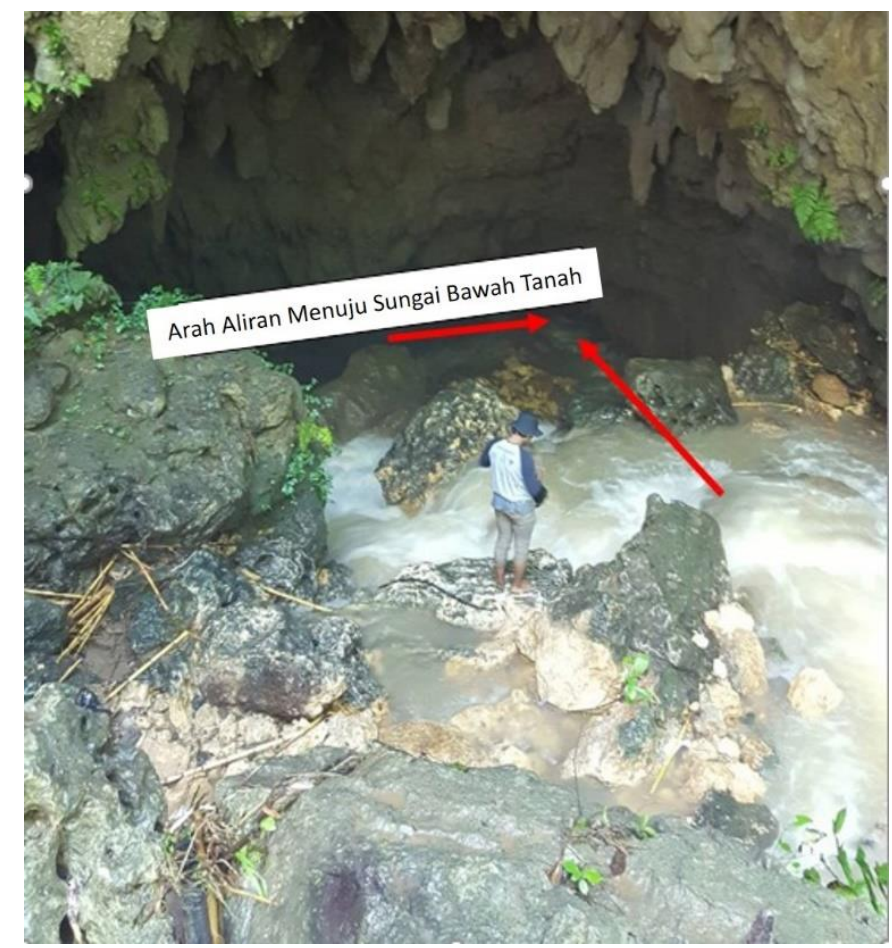

Gambar 3. Ponor Seropan Sebagai Outlet dari Tiga Sungai Permukaan dan Inlet untuk Sungai Bawah Tanah di Kawasan Karst Gunungsewu

Mataair Beton adalah salah satu resurgence (kemunculan sungai bawah tanah di permukaan Bumi) dengan debit besar di Kawasan Karst Gunungsewu. Kemunculannya terdapat pada perpindahan morfologi perbukitan karst menuju ke suatu Polje yang berupa dataran. Perubahan morfologi yang mendadak menghasilkan pemotongan terhadap sungai bawah tanah yang terletak pada muka airtanah.
Perubahan morfologi yang mendadak ini dalam peta Geologi Lembar Surakarta skala 1:100.000 yang disusun oleh Surono et al (1992) dianalisis sebagai akibat keberadaan patahan.

Hasil analisis terhadap uji perunutan diketahui bahwa terdapat keterhubungan antara Ponor Seropan dan Mataair Beton (Gambar 4). Hal ini ditandai dengan terdeteksinya larutan uranin yang 
dilepaskan di Ponoro Seropan oleh fluorometer yang dipasang di Mataair Beton. Selain itu, hasil uji perunutan menunjukkan bahwa Ponor Seropan tidak terhubung dengan Mataair Gremeng, karena fluorometer yang dipasang di Mataair Gremeng tidak mendeteksi konsentrasi uranin. Hasil ini membantah hasil kajian yang dilakukan oleh Budiyanto dan Lestari (2019) yang memasukkan wilayah di Ponor Seropan sebagai bagian dari Mataair Gremeng. Perbedaan hasil ini disebabkan karena metode yang digunakan berbeda. Pembatasan wilayah tangkapan Matair Gremeng oleh Budiyanto dan Lestari (2019) hanya didasarkan pada bentuk permukaan (morfologi) yang diolah dari citra penginderaan jauh tanpa melakukan pemetaan bawah permukaan ataupun uji perunutan.
Hasil perekaman konsentrasi uranin pada Fluorometer selama melakukan uji perunutan disajikan pada Gambar 5. Larutan Uranin terdeteksi pada menit ke 90 dan mulai hilang pada menit ke 180. Waktu ini tergolong sangat cepat baik dari waktu terdeteksi dan waktu kembalinya. Breaktroughcurve yang terbentuk berupa kurva tunggal dengan sayap naik ataupun sayap turun memiliki bentuk yang terjal. Hal tersebut mengindikasikan telah berkembangnya lorong pada sistem hidrogeologi yang dikaji. Selain itu, Breaktroughcurve yang berbentuk kurva tunggal dengan satu puncak menunjukkan bahwa lorong yang terbentuk pada sistem hidrogeologi yang dikaji berupa single conduit.

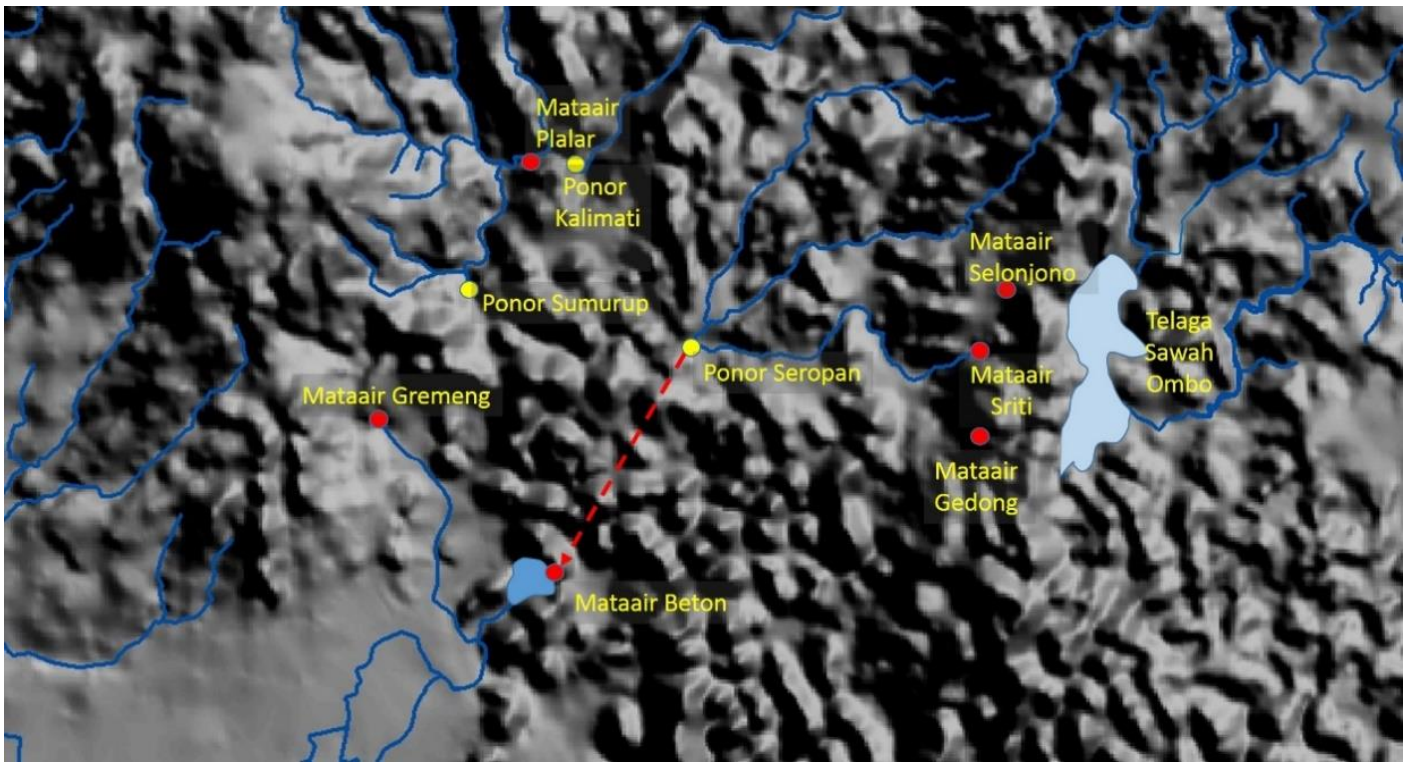

Gambar 4. Konektivitas Ponor Seropan dan Matair Beton

Perkembangan lorong berupa single conduit umum terjadi pada sistem hidrogeologi karst yang dikontrol oleh sungai alogenik (Palmer, 2001; Palmer, 2007). Hasil kajian ini memiliki karakter yang sama dengan sistem sungai bawah tanah Anjani di Kawasan Karst Jonggrangan (Kabupaten Kulon Progo dan Kabupaten
Purworejo) yang juga diimbuh oleh aliran sungai alogenik melalui Ponor Semar. Selain menghasilkan lorong dengan tipe single conduit, sistem hidrogeologi karst yang dipengaruhi oleh alogenik dapat pula menghasilkan tipe maze cave (sistem lorong yang bercabang banyak). Namun demikian, sistem hidrogeologi yang memiliki 
kemiringan aliran yang besar dan debit aliran sungai alogenik yang besar (meskipun tidak sepanjang tahun) akan cenderung menghasilkan tipe lorong single conduit seperti pada penelitian ini.

Perkembangan lorong yang telah sangat intensif ditandai dengan respon terhadap artifisial tracer yang sangat cepat menunjukkan bahwa sistem hidrogeologi Mataair Beton memiliki kerentanan yang tinggi terhadap pencemaran (Worthington, 2011). Hal serupa dikemukakan Pratiwi (2013) dalam penelitian terkait dengan pemetaan kerentanan airtanah di lokasi kajian dengan menggunakan metode EPIK. Masuknya air sungai alogenik melalui ponor akan menyebabkan airtanah dalam sungai bawah tanah mudah mengalami pencemaran. Hal ini berbeda ketika aliran airtanah meresap melalui lorong antar butir atau lorong pelarutan dengan ukuran sangat kecil, maka air yang masuk ke sungai bawah tanah akan mengalami penyaringan secara alamiah. Oleh karenanya, pengelolaan sistem hidrogeologi Beton sebaiknya tidak hanya terbatas pada kawasan karstnya saja, tetapi juga pada wilayah tangkapan air yang mensuplai air melalui sungai alogenik.

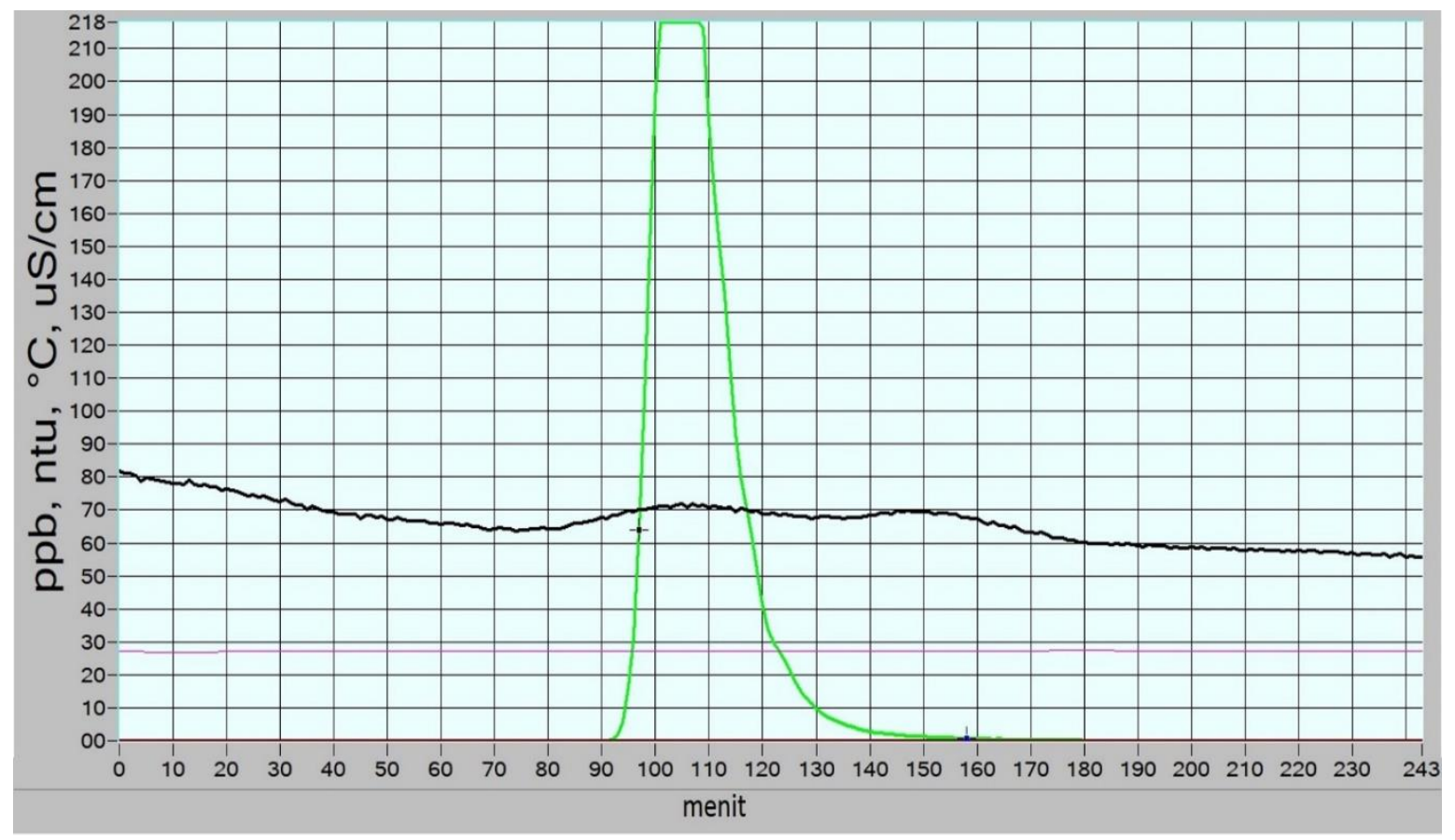

Gambar 5. Hasil Perekaman Konsentrasi Uranin (wahrna hijau) pada Fluorometer Selama Uji Perunutan

\section{KESIMPULAN}

Uji perunutan di lokasi kajian menunjukkan konektivitas antara Ponor Seropan dan Mataair Beton. Breaktrough curve hasil pencatatan fluorometer menunjukkan kurva tunggal yang berarti lorong yang berkembang berupa single conduit. Bentuk breaktrough curve yang naik tajam dan kembali secara cepat menunjukkan lorong yang terbentuk memiliki ukuran yang sudah cukup berkembang (besar) dan tidak terbentuk kolam (pool) di dalam lorong. Berdasarkan pada imbuhan airtanah yang terkoneksi dengan aliran sungai alogenik dan sifat lorong yang telah berkembang, maka sistem hidrogeologi Mataair Beton memiliki kerentanan airtanah yang tinggi. Perlindungan sistem hidrogeologi ini tidak cukup hanya di kawasan karst saja, tetapi juga perlu pada wilayah tangkapan air dari 
ge Ografi

sistem sungai alogenik di bagian hulu yang mencakup wilayah non-karst.

\section{UCAPAN TERIMAKASIH}

Penelitian ini merupakan bagian kecil dari Disertasi penulis pertama. Sebagian disertasi yang ditulis dalam paper ini dibiayai oleh hibah penelitian mandiri dosen Fakultas Geografi Universitas Gadjah Mada tahun nggaran 2019. Penulis mengucapkan terima kasih kepada pihak Fakultas Geografi UGM yang telah memberikan hibah penelitian kepada kami. Tidak lupa penulis mengucapkan terima kasih kepada Hamzah Fathoni, S.Si.; Aji Dwi Pratama, S.Si.; dan Nandha Setiawan dari Departemen Geografi Lingkungan, Fakultas Geografi UGM yang telah membantu kegiatan lapangan penelitian ini.

\section{DAFTAR PUSTAKA}

Akmaluddin, D., Watanabe, K., \& Itaya, T. (2005). New Interpretation On Magmatic Belts Evolution During the NeogeneQuaternary Periods as Revealed from Newly Collected K-Ar Ages from Central-East Java, Indonesia (Doctoral Dissertation, Hagi-Iagi-Perhapi).

Behrens, H., Beims, U., Dieter, H., Dietze, G., Eikmann, T., Grummt, T., ... \& Leibundgut, C. (2001). Toxicological and Ecotoxicological Assessment of Water Tracers. Hydrogeology Journal, 9(3), 321325.

Benischke, R., Goldsceider, N., \& Smart, C. (2007). Tracer Techniques. In Goldsceider, N., \& Drew, D (eds). Methods in Karst Hydrogeology. Taylor \& Francis Group, London.

Bronto, S., Mulyaningsih, S., Hartono, G., \& Astuti, B. (2009). Waduk Parangjoho dan Songputri: Alternatif Sumber Erupsi Formasi Semilir di daerah Eromoko, Kabupaten Wonogiri, Jawa
Tengah. Indonesian

Journal

on

Geoscience, 4(2), 77-92.

Budiyanto, E. \& Lestari, E.P. (2019). Sensitivitas Mata Air Karst Goa Gremeng terhadap Hujan di Area Tangkapannya. Jurnal Geografi: Geografi dan Pengajarannya, 17(1): 63 - 70.

Cahyadi, A. dan Agniy, R.F. (2016). Analisis Breakthrough Curve untuk Karakteristerisasi Pelorongan Di Sistem Sungai Bawah Tanah Pindul Kabupaten Gunungkidul. Prosiding Pertemuan Ilmiah Tahunan Ke-1 Perhimpunan Ahli Airtanah Indonesia (PIT-PAAI). ITB Press, Bandung.

Cahyadi, A., Riyanto, I.A., Adji, T.N., Tivianton, T.A., Agniy, R.A., Ramadhan, F., Naufal, M., dan Saputro, T.C. (2018a). Hidrostratigrafi dan Dampaknya pada Kemunculan Mataair di Sub-Sistem Panggang, Kawasan Karst Gunungsewu, Kabupaten Gunungkidul. Prosiding Seminar Geografi II. Fakultas Geografi UGM, Yogyakarta.

Cahyadi, A.; Riyanto, I.; Irshabdillah, M.R. dan Firizqi, F. (2018b). Inventarisasi dan Karakterisasi Sistem Aliran Sungai Alogenik di Kawasan Karst Gunungsewu Kabupaten Gunungkidul. Laporan Penelitian. Faculty of Geography, Universitas Gadjah Mada, Yogyakarta.

Field, M.S. (2003). A Review of Some TracerTest Design Equations for Tracer-Mass Estimation and Sample-Collection Frequency. Environmental Geology, 43: 867-881.

Field, M.S. (2005). Tracer-Test Design for Losing Stream-Aquifer Systems. International Journal of Speleology, 35(1): 25-36.

Ford, D. \& Williams, P. (2007). Karst Hydrology and Geomorphology. John Wiley and Sons, Ltd., Chichester, West Sussex.

Gilli, E. (2015). Karstology - Karst, Caves and Springs: Elements of Fundamental and 
ge Ografi

Applied Karstology. CRC Press, Boca Raton.

Goldscheider, N., Meiman, J., Pronk, M \& Smart, C. (2008). Tracer Tests in Karst Hydrogeology and Speleology. International Journal of Speleology, 37 (1): 27-40.

Haryono, E. (2011). Introduction to Gunungsewu Karst: Field Guide of Asian Trans-Disciplinary Karst Conference. Karst Research Group, Faculty of Geography, Universitas Gadjah Mada, Yogyakarta.

Hayono, E.; Barianto, D.H. \& Cahyadi, A. (2017). Hidrogeologi Kawasan Karst Gunungsewu: Panduan Lapangan Fieldtrip PIT PAAI ke-2. Perhimpunan Ahli Airtanah Indonesia (PAAI), Yogyakarta.

Hess, J.W. \& White, W.B. (1989). Chemical Hydrology. In White, W.B. \& White, E.L. (eds). Karst Hydrology: Concepts from the Mammoth Cave Area. Springer, New York.

Käss, W. (1998). Tracing Technique in Geohydrology. Balkema, Rotterdam.

Leibundgut, C., Maloszewski, P. \& Külls, C. (2009). Tracer Hydrology. WileyBlackwell, New York.

Lestari, Y., Haryono, E. \& Fatchurohman, H. (2014). Identifikasi Tingkat Kekritisan Daerah Tangkapan Air sebagai Penentuan Arahan Pengelolaan: Studi Kasus Daerah Tangkapan Mataair Beton, Ponjong, Gunungkidul. dalam Cahyadi, A., Prabawa, B.A., Tivianton, T.A. \& Nugraha, H. Ekologi Lingkungan Kawasan Karst Indonesia: Menjaga Asa Kelestarian Kawasan Karst Indonesia, Edisi Dua. Deepublish, Yogyakarta.

Palmer, A.N. (2001). Dynamics of Cave Development by Allogenic Water. Acta Carsologica, 30(2): 13-32.

Palmer, A.N. (2007). Cave Geology. Caves Books, Dayton, Ohio.

Pratiwi, E.S. (2013). Kelemahan dan Kendala Penerapan Metode EPIK dalam
Menentukan Zonasi Kerentanan Airtanah Intrinsik di Kawasan Karst Gunungsewu, Indonesia. dalam Sudarmadji, Haryono, E., Adji, T.N., Widyastuti, M., Harini, R., Nurjani, E., Cahyadi, A. \& Nugraha, H. (eds.). Ekologi Lingkungan Kawasan Karst Indonesia: Menjaga Asa Kelestarian Kawasan Karst Indonesia. Deepublish, Yogyakarta.

Riyanto, I.A., Cahyadi, A., Adji, T.N., Haryono, E., Widyastuti, M., Agniy, R.F., Fathoni, W.A., Rahmawati, N., \& Baskoro, H. (2018). Analisis Konektivitas dan Karakterisasi Pelorongan dengan Uji Perunutan pada Mataair Epikarst Sub-sistem Panggang, Kawasan Karst Gunungsewu. Prosiding Pertemuan Ilmiah Tahunan Perhimpunan Ahli Airtanah Indonesia (PAAI). ITB Press, Bandung.

Stanley, N.D., Thomson, G.M., Bentley, H.W. \& Styles, G. (1980). Groundwater Tracer: A Short Review. Groundwater Journal, 18(1): 14-21.

Surono, B.T.; Sudarno, I. and Wiryosujono, S. (1992). Peta Geologi Lembar Surakarta 1:100,000. Badan Geologi, Bandung.

Surono. (2008). Sedimentasi Formasi Semilir di Desa Sendang, Wuryantoro, Wonogiri, Jawa Tengah. Jurnal Sumber Daya Geologi, 28(1): 29-41.

van Bemmelen, R.W. (1949). The Geology of Indonesia, Vol. 1A, General Geology. Martinus Nijhoff, The Hague.

White, W.B. 1988. Geomorphology and Hydrology of Karst Terrains. Oxford University Press, New York.

Worthington, S.R.H. (2011). Management of Carbonate Aquifers. In van Beynen, P.E. (ed). 2011. Karst Management. Springer, Dordrech 